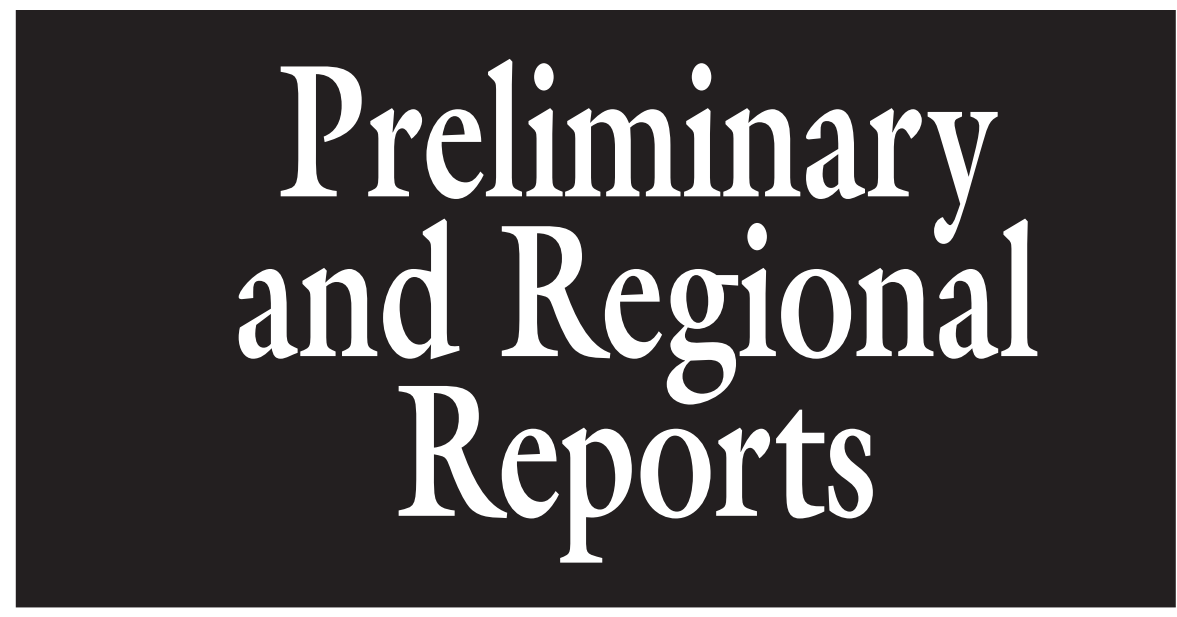

\section{Field Evaluation of Pollen-free Sunflower Cultivars for Cut Flower Production}

\author{
R. Crofton Sloan ${ }^{1}$ and Susan S. Harkness ${ }^{2}$
}

\section{AdDitional INDEX wORDs. Helianthus annuus, cut flower, field production}

SUMMARY. Thirteen single-stem and 16 branching sunflower (Helianthus annuus) cultivars were evaluated in field trials at the North Mississippi Research and Extension Center in Verona for cut flower production. The objective of this study was to assess the production potential of field-grown, pollen-free sunflowers in the Mississippi environment. The stem length, stem diameter, and bloom diameter of the sunflower cultivars were assessed over six planting dates during the summer growing season to determine cultivar market potential. All the single-stem cultivars produced stem diameters greater than $1.4 \mathrm{~cm}$ and were too large for general florist usage. The stems and flowers of the branching cultivars were smaller than the single-stem cultivars, and were a better size for many floral arrangements. The yield of stems from the branching cultivars ranged from three to 13 stems per plant over six planting dates. In the branching group, the darkflowered cultivars produced the greatest number and the longest stems in the trial. Yellow/gold-flowered branching sunflowers in this trial did not produce as many stems and the stem lengths were shorter compared to the dark-flowered sunflowers.

S unflowers are a popular fresh, cut flower because the bright flowers are often credited with creating a cheerful, sunny atmosphere. The wholesale value of cut flower sunflowers sold in the United States in 1998 was $\$ 4,423,000$ (U.S. Dept. of Agriculture, 1998). The 67 species of sunflowers in the genus Helianthus are all native to the southwestern U.S.

North Mississippi Research and Extension Center, P.O. Box 1690, Verona, MS 38879.

Contribution of the Mississippi Agricultural and Forestry Experiments Station journal article no. J-10755 Mention of trademark or proprietary product does not constitute a guarantee or warranty of the product and does not imply its approval to the exclusion of other products that may also be suitable.

${ }^{1}$ Assistant Research Professor.

${ }^{2}$ Research Associate II. and Mexico (Heiser, 1978). Two species, $H$. annums and $H$. tuberosus, have historically been used as food crops, and sunflowers were cultivated in the southwestern U.S. around $3000 \mathrm{BCE}$ (Putt, 1978). Putt (1978) postulated that the American Indians cultivated sunflowers before corn (Zea mays) was domesticated. Samuel de Champlain, the French explorer, reported seeing sunflowers growing in gardens of the
Huron Indians in the St. Lawrence River area of North America in 1615 (Hedrick, 1950). Native Americans grew sunflowers for the seeds that were roasted and eaten, ground into flour, or treated so that the oil could be extracted. Spanish explorers brought sunflower seed from the New World to Spain. The first published description of the sunflower in Europe was by Belgian herbalist Rembert Dodoens in 1568 (Heiser, 1976). Sunflower seed was disseminated from Spain across Europe where it was primarily utilized as an ornamental plant, although by the 18 th century sunflower seeds were considered a food delicacy (Putt, 1978).

The common sunflower $(H$. annuns) often is utilized today as an ornamental plant. A genetic mutation that resulted in the double sunflower must have occurred during the 17th century in Europe since it appears in contemporary garden illustrations (Heiser, 1976). Mrs. T.D.A. Cockerell observed a red sunflower among a group of yellow sunflowers in Colorado in 1910. She and her husband transplanted the mutant to their garden, saved seed from the plant, and conducted their own breeding program to produce seed for red sunflowers (Heiser, 1976).

Sunflowers are considered an easy crop to grow for cut flower growers, and the pollen-free cultivars are preferred because they have a longer vase life and are cleaner in an arrangement compared to cultivars with pollen (Armitage, 1993). Recently, plant breeders have developed numerous ornamental sunflower cultivars that are grown for cut flower production. In 2001 there were six new sunflowers evaluated in the field trials of the Association of Specialty Cut Flower Growers (Dole, 2002). In 2002, 17 cultivars, some with bloom colors such as green, peach, bronze, as well as traditional, dark-disc with yellow petals, were included in the on-farm field trials (Dole, 2003). Participants in these on-farm evaluations commented that some of the cultivars were too large for florist us-

\begin{tabular}{llll}
\hline $\begin{array}{l}\text { Units } \\
\begin{array}{l}\text { To convert U.S. to SI, } \\
\text { multiply by }\end{array}\end{array}$ & U.S. unit & SI unit & $\begin{array}{l}\text { To convert SI to U.S., } \\
\text { multiply by }\end{array}$ \\
\hline 8.0520 & $\mathrm{gal} / 100 \mathrm{ft}$ & $\mathrm{L} \cdot \mathrm{m}^{-1}$ & 0.1242 \\
2.5400 & inch $(\mathrm{es})$ & $\mathrm{cm}$ & 0.3937 \\
1.1209 & lb/acre & $\mathrm{kg} \cdot \mathrm{ha}^{-1}$ & 0.8922 \\
7.4892 & $\mathrm{oz} / \mathrm{gal}$ & $\mathrm{g} \cdot \mathrm{L}^{-1}$ & 0.1335 \\
1 & $\mathrm{ppm}$ & $\mathrm{mg} \cdot \mathrm{L}^{-1}$ & 1
\end{tabular}


age while other cultivars branched too freely and produced stems and flowers that were unacceptably small (Dole, 2002, 2003). Research in Florida was conducted to attempt to reduce stem and flower size of sunflowers (Emino and Hamilton, 2004). 'Sunbright', a single-stem cultivar, when pinched 3 weeks after planting, produced 36-inch stems from the lateral buds while the non-pinched stems grew to 60 inches. Another trial indicated that spacing 'Superior Sunset' plants 3 inches within the row, compared to 6 or 9 inches, was necessary to reduce stem size (Sloan et al., 2004). Florists in Tupelo, Miss., indicated that the desirable sunflower stem size for general floral arrangements would be 60-90 $\mathrm{cm}$ long, $0.5-1.5 \mathrm{~cm}$ stem diameter, and the bloom would be $8-15 \mathrm{~cm}$ in diameter (R.C. Sloan, unpublished). Sunflowers have been identified as a field-grown cut flower crop with potential for production in Mississippi (Sloan and Harkness, 2002). In general, the growth response and market acceptance have been good (Sloan et al., 2003). Preliminary investigations indicate that field-grown sunflowers can be profitably produced on a small scale for local consumption (Romo Leroux et al., 2003). The intent of this study was to evaluate the plant growth parameters of stem length and diameter, bloom diameter, and time required for harvest over the time frame of a summer growing season for field-grown, pollen-free sunflowers for cut flower utilization.

\section{Materials and methods}

Thirteen single-stem and 16 branching, pollen-free, sunflower cultivars (Tables $1-3$ ) were evaluated for growth characteristics in field beds on a Savannah sandy clay loam soil at the North Mississippi Research and Extension Center, Verona (lat. $34.2^{\circ} \mathrm{N}$, long. $88.8^{\circ} \mathrm{W}$ ). Seeds were planted in 1204 cells $(1.50 \times 2.37 \times$ 2.37 inches) on six dates: 25 Apr., 13 June, 30 June, 15 July, 8 Aug., and 8 Aug. 2003. Seedlings were fertilized with $100 \mathrm{mg} \cdot \mathrm{L}^{-1}$ nitrogen using Peter's Peat Lite Special 20-10-20 (20N-4.3P-16.7K; The Scotts Co., Marysville, Ohio) water-soluble fertilizer until the first leaves emerged; then they were fertilized weekly with $250 \mathrm{mg} \cdot \mathrm{L}^{-1}$ nitrogen from $20-10-20$ water-soluble fertilizer. The seedlings were drenched with $15 \%$ etridiazole $+25 \%$ thiophanate methyl (Banrot; Scotts-Sierra Crop Protection Co., Marysville, Ohio) at a 2-oz/gal rate of formulation prior to transplanting to the field beds.

Preplant fertilizer $8-8-8(8 \mathrm{~N}-$ 3.5P-6.6K) (IMC Rainbow Agribusiness, Florence, Ala.) was applied to the field at a rate of $436 \mathrm{lb} /$ acre. Raised beds were formed with a three-point hitch bed shaper and covered with plastic mulch. The beds were 30 inches across the top and were spaced on $5-\mathrm{ft}$ centers. A single drip tape was placed in the center of the bed and buried 1 inch below the bed surface. Seedlings were transplanted to raised beds on six dates: 19 May, 7 July, 15 July, 5 Aug., 26 Aug., and 10 Sept. 2003. Beds were fertigated weekly with Peter's $20-20-20(20 \mathrm{~N}-8.8 \mathrm{P}-16.5 \mathrm{~K})$ at a rate of $24 \mathrm{lb} /$ acre during the growing season. Irrigation was supplied in the absence of rain through the drip tape to provide $125 \mathrm{gal} / 100 \mathrm{ft}$ (linear) of row once per week until harvest. The terminal bud of the branching cultivars was removed when the plant reached the four- to six-node stage of development to encourage the development of multiple stems.

Experimental units consisted of two plants of each cultivar that were planted in pairs, one plant on each of two parallel rows that were spaced 12 inches apart. The single-stem and branching cultivars were planted in different areas of the field and were treated as separate experiments. Single-stem cultivars were spaced 6 inches apart in the row while the branching cultivars were spaced 12 inches apart.

Sunflower stems were harvested as soon as the blooms were completely opened. Stems were cut at $90 \mathrm{~cm}$, if the stem was longer than $90 \mathrm{~cm}$, or were measured if less than $90 \mathrm{~cm}$. Stem diameters were measured 90 $\mathrm{cm}$ below the bloom, or at the base of the stem if it was shorter than $90 \mathrm{~cm}$. The stem length was measured from the base of the stem to the upper edge of the bloom. The bloom diameter was measured from edge to edge of the petals.

The experimental design for each planting date was a randomized

Table 1. The stem length and diameter, bloom diameter, and the time required for harvest of single-stem sunflower cultivars were observed over six planting dates in 2003.

\begin{tabular}{|c|c|c|c|c|c|}
\hline Cultivar & $\begin{array}{c}\text { Bloom } \\
\text { description }\end{array}$ & $\begin{array}{l}\text { Time from } \\
\text { seeding to } \\
\text { harvest }(\mathrm{d})^{\mathrm{z}}\end{array}$ & $\begin{array}{l}\text { Stem } \\
\text { length }^{\mathrm{z}} \\
(\mathrm{cm})^{\mathrm{y}}\end{array}$ & $\begin{array}{c}\text { Stem } \\
\operatorname{diam}^{z} \\
(\mathrm{~cm})\end{array}$ & $\begin{array}{c}\text { Bloom } \\
\operatorname{diam}^{z}(\mathrm{~cm})\end{array}$ \\
\hline Superior Gold & Light golden yellow with dark disc & $63.8 \mathrm{ab}$ & $91.0 \mathrm{a}$ & $2.4 \mathrm{a}$ & $19.7 \mathrm{a}$ \\
\hline Full Sun & Canary yellow with dark disc & $62.1 \mathrm{a}-\mathrm{c}$ & $91.0 \mathrm{a}$ & $2.3 \mathrm{ab}$ & $19.6 \mathrm{a}$ \\
\hline Full Sun Improved & Canary yellow with dark disc & $61.7 \mathrm{a}-\mathrm{c}$ & $91.0 \mathrm{a}$ & $2.4 \mathrm{a}$ & $18.4 \mathrm{ab}$ \\
\hline Sunrich Orange & Golden orange with dark disc & $59.1 \mathrm{bc}$ & $91.0 \mathrm{a}$ & $1.6 \mathrm{c}$ & $15.7 \mathrm{c}-\mathrm{e}$ \\
\hline Sunrich Lemon & Bright yellow with dark disc & $57.7 \mathrm{~cd}$ & $90.4 \mathrm{a}$ & $1.5 \mathrm{c}$ & $14.8 \mathrm{de}$ \\
\hline Dorado Select & Orange with dark disc & $53.7 \mathrm{de}$ & $87.0 \mathrm{~b}$ & $1.9 \mathrm{a}-\mathrm{c}$ & $11.6 \mathrm{f}$ \\
\hline Summertime & Yellow with dark disc & $53.7 \mathrm{de}$ & $90.9 \mathrm{a}$ & $1.4 \mathrm{c}$ & $13.7 \mathrm{ef}$ \\
\hline Orange Mahogany & Mahogany, gold tips with dark disc & $53.4 \mathrm{de}$ & $90.7 \mathrm{a}$ & $1.5 \mathrm{c}$ & $13.7 \mathrm{ef}$ \\
\hline
\end{tabular}

${ }^{2}$ Means of six observation dates.

${ }^{\mathrm{y}} \mathrm{l} \mathrm{cm}=0.3937$ inch.

${ }^{x}$ Mean comparison within columns by Fisher's protected least significant difference at $P=0.05$. Means with the same letter do not differ at the $5 \%$ significance level. 
Table 2. The number of stems/plant, stem length, and stem diameter of secondary stems of single-stem sunflower cultivars planted 19 May 2003 were measured.

\begin{tabular}{lccl}
\hline Cultivar & $\begin{array}{c}\text { Stems } \\
(\text { no. } / \text { plant })\end{array}$ & $\begin{array}{c}\text { Stem } \\
\text { length } \\
(\mathbf{c m})^{\mathrm{z}}\end{array}$ & $\begin{array}{c}\text { Stem } \\
\text { diam } \\
(\mathbf{c m})\end{array}$ \\
\hline Orange Mahogany & $7.0 \mathrm{a}^{\mathrm{y}}$ & $52.8 \mathrm{a}-\mathrm{c}$ & $0.88 \mathrm{bc}$ \\
Sunny & $3.8 \mathrm{~b}$ & $48.4 \mathrm{bc}$ & $0.84 \mathrm{c}$ \\
Superior Sunset & $3.6 \mathrm{bc}$ & $57.8 \mathrm{ab}$ & $1.18 \mathrm{ab}$ \\
Full Sun & $3.6 \mathrm{bc}$ & $55.0 \mathrm{ab}$ & $1.34 \mathrm{a}$ \\
Dorado Select & $3.1 \mathrm{~b}-\mathrm{d}$ & $60.8 \mathrm{a}$ & $0.73 \mathrm{c}$ \\
Superior Gold & $2.0 \mathrm{~b}-\mathrm{e}$ & $59.9 \mathrm{a}$ & $1.37 \mathrm{a}$ \\
Full Sun Improved & $1.8 \mathrm{~b}-\mathrm{e}$ & $58.0 \mathrm{ab}$ & $0.94 \mathrm{bc}$ \\
Sunsplash & $1.6 \mathrm{c}-\mathrm{e}$ & $48.9 \mathrm{bc}$ & $0.84 \mathrm{c}$ \\
Goldburst & $1.1 \mathrm{de}$ & $44.4 \mathrm{c}$ & $1.19 \mathrm{ab}$ \\
\hline
\end{tabular}

${ }^{\mathrm{z}} 1 \mathrm{~cm}=0.3937$ inch.

'Mean comparison within columns by Fisher's protected least significant difference at $P=$ 0.05. Means with the same letter do not differ at the $5 \%$ significance level.

complete block with four replications. The data from measurements of the single-stem and branching cultivars were analyzed over the six planting dates using a mixed model with planting date, replication within planting date, and cultivar $\times$ planting date being the random effects. The data were averaged over the six planting dates rather than analyzed for each separate planting date. The intent of the study was to consider the sunflower stem length, diameter, and bloom diameter over six planting dates during the summer growing season. The fact that the results seen over the six planting dates might not hold for every time period in the presence of an interaction is recognized. The branching cultivars were grown and analyzed separately from the single-stem cultivars. Data collected during the trial were analyzed by SAS PROC Mixed (SAS Institute, Cary, N.C.). Mean separation was conducted with Fisher's protected least significant difference (LSD) at the 0.05 significance level.

\section{Results and discussion}

SINGLE-STEM SUNFLOWER CULTIVARs. Summer 2003 was relatively cool with high temperatures of 87 and $89{ }^{\circ} \mathrm{F}$ recorded in July and August, respectively, due, in part, to above average rainfall in May, June, August, and September (North Mississippi Research and Extension Center, 2004). The interval between seeding and harvest of 'Brilliance', 'Sunsplash', 'Orange Mahogany', 'Summertime', and 'Dorado Select' was shorter than 'Sunny', 'Superior Gold', 'Full Sun', 'Full Sun Improved', 'Superior Sunset', and 'Goldburst' (Table 1). The stem diameters ranged from $1.4-2.4 \mathrm{~cm}$ in diameter $90 \mathrm{~cm}$ below the bloom. Stem diameters of 'Full Sun Improved', 'Superior Gold', 'Full Sun', and 'Superior Sunset' were at least $2.3 \mathrm{~cm}$ and were statistically larger than the other cultivars except 'Dorado Select'. These stems were too large for general florist use. The bloom diameter of these cultivars ranged from $11.6-19.7 \mathrm{~cm}$. All of the single-stem sunflowers, except 'Dorado Select', grew at least $90 \mathrm{~cm}$ tall; many were much taller. 'Dorado Select' produced an average stem length of $87.0 \mathrm{~cm}$. Sunflowers with the largest stem diameters also produced the largest flowers. 'Dorado Select' produced the smallest blooms, 11.6 $\mathrm{cm}$, of the single-stem cultivars.

Nine of the 14 single-stem cultivars from the 19 May planting date produced secondary stems after the terminal stem had been harvested (Table 2). The secondary stems were not harvested if they were less than 40 $\mathrm{cm}$ long or $0.5 \mathrm{~cm}$ in diameter. 'Orange Mahogany' produced more secondary

Table 3. The number of stems/plant, stem length and diameter, bloom diameter, and the time required for harvest of branching sunflower cultivars were observed over six planting dates in 2003.

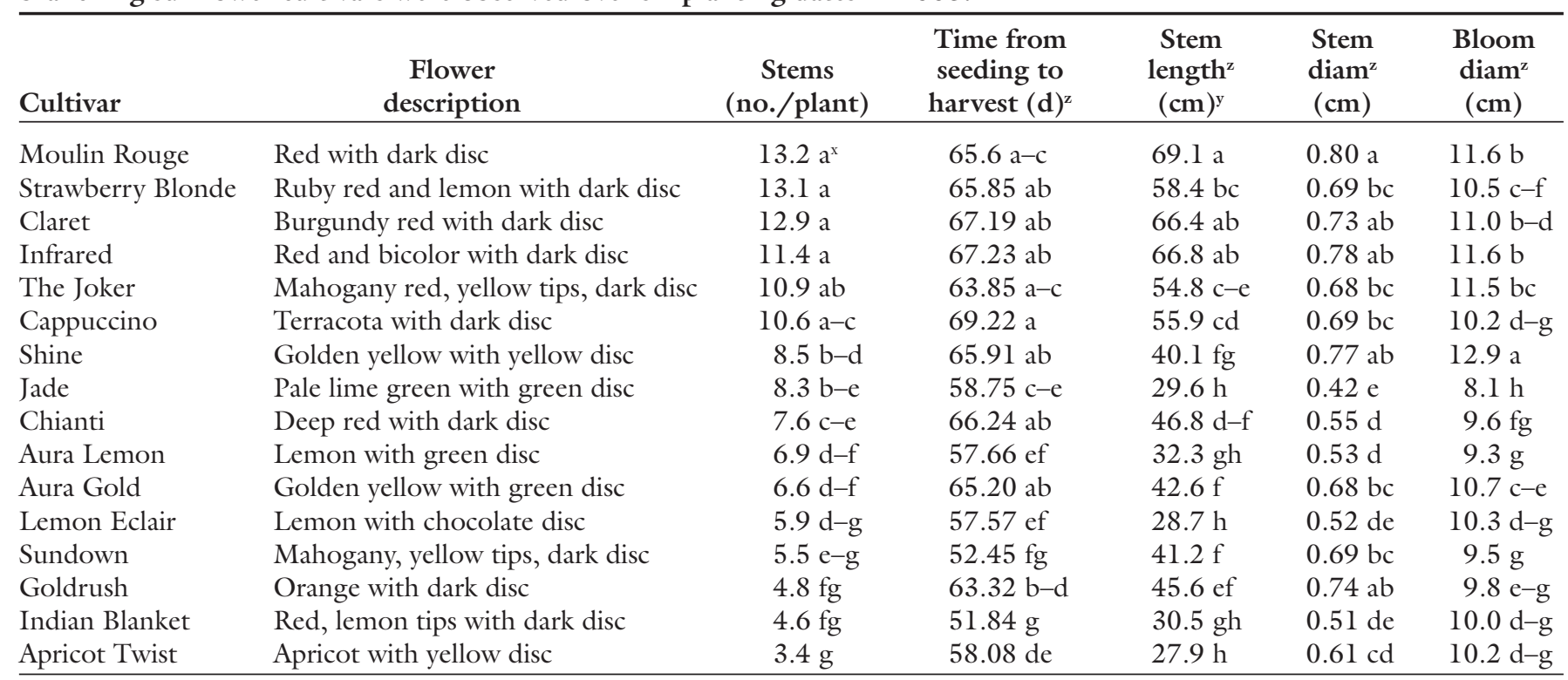

${ }^{2}$ Means of six observation dates.

y $1 \mathrm{~cm}=0.3937$ inch.

'Mean comparison within columns by Fisher's protected least significant difference at $P=0.05$. Means with the same letter do not differ at the $5 \%$ significance level. 
stems than all the other single-stem cultivars. The stem length of the secondary stems ranged between 44.4-60.8 $\mathrm{cm}$. The secondary stem diameters of 'Superior Gold' and 'Full Sun' were larger than the other cultivars except 'Goldburst' and 'Superior Sunset'. There were no significant differences in bloom diameter. The secondary stems of 'Orange Mahogany' averaged 52.8 $\mathrm{cm}$ long and $0.88 \mathrm{~cm}$ in diameter while the blooms were $9.9 \mathrm{~cm}$ across, and were satisfactory for florist use.

BRANCHING SUNFLOWER CULTIVARs. The number of stems from the branching cultivars ranged from three to 13 stems/plant over the six planting dates (Table 3). 'Moulin Rouge', 'Strawberry Blonde', 'Claret', and 'Infrared' produced more stems than all other branching cultivars except 'The Joker' and 'Cappuccino'. These cultivars produce dark-colored blooms. The stem lengths of 'Moulin Rouge', 'Infrared', and 'Claret' were longer than the other branching cultivars except 'Strawberry Blonde' and ranged from $66.4-69.1 \mathrm{~cm}$ long. 'Apricot Twist', 'Lemon Éclair', and 'Jade' produced the shortest stems except for 'Indian Blanket' and 'Aura Lemon' and ranged from 27.9-29.6 $\mathrm{cm}$ long. 'Apricot Twist', 'Aura Lemon', 'Lemon Éclair', 'Sundown', and 'Indian Blanket' required fewer days from planting to harvest compared to 'Cappuccino', 'Infrared', 'Claret', 'Chianti', 'Strawberry Blonde', 'Shine', 'Moulin Rouge', 'Aura Gold', and 'The Joker'. The stem diameters of the 16 branching cultivars ranged from $0.42-0.80 \mathrm{~cm}$. Except for the smallest cultivars, the stem diameters of the branching cultivars in this trial should be acceptable for florist use. 'Shine' produced the largest blooms of the branching cultivars while 'Jade' produced the smallest blooms.

The branching cultivars producing the most stems with the longest stem length were dark-flowered sunflowers. The branching cultivars with the yellow / gold petals and dark center disc did not produce as many stems, but the least productive cultivar still produced three stems per plant. One problem observed with the yellow/ gold-flowered branching sunflowers was that one plant of the pair of plants evaluated for each cultivar grew weakly compared to the other plants. This reduced the average number of stems produced and stem length.

\section{Conclusions}

There is a wide variation in the size of cut sunflower stems commercially available for florists. Floral arrangers are artistic, creative individuals who use large or small sunflower stems and blooms depending on the size of the arrangement and personal preference. For discussion purposes in this study, the standard-sized sunflower stem for general florist use, based on communications with florists in Tupelo, Miss., was determined to be $60-90 \mathrm{~cm}$ stem length, $0.5-1.5 \mathrm{~cm}$ stem diameter, and $8-15 \mathrm{~cm}$ bloom diameter. Single-stem cultivars Full Sun Improved, Superior Gold, Full Sun, and Superior Sunset produced the largest stems and blooms in this trial, and were too large for general florist use. Close plant spacing or terminal pinching should be considered for these single-stem cultivars to reduce stem and bloom size. Other yellow/gold-flowered single-stem cultivars, such as 'Orange Mahogany', 'Sunrich Lemon', and 'Summertime', had smaller stem diameters that would be satisfactory for general use.

Results from this research indicate that the dark-flowered branching cultivars Moulin Rouge, Claret, Infrared, Cappuccino, Strawberry Blonde, and The Joker produced the largest number of stems per plant. The yellow/goldflowered branching sunflowers in this trial did not produce as many stems and the stem lengths were shorter compared to the dark-flowered cultivars, but they would still be satisfactory for florist use.

\section{Literature cited}

Armitage, A.M. 1993. Specialty cut flowers. Varsity Press/Timber Press. Portland, Ore.

Dole, J. 2002. 2001 ASCFG national cut flower seed trials. Cut Flower Quarterly 14(1):1-14.

Dole, J. 2003. 2002 ASFCG national cultivar flower seed trials. Cut Flower Quarterly 15(1):7-22.

Emino, E.R. and B. Hamilton. 2004. Back to basics. Cut Flower Quarterly 16 (4):12-13.

Hedrick, U.P. 1950. The history of horticulture in America. Oxford Univ. Press, New York.

Heiser, C.B. 1976. The sunflower. Univ. Oklahoma Press. Norman.

Heiser, C.B. 1978. Taxonomy of Helianthus and origin of domesticated sunflower. p. 31-51. In: J.F. Carter (ed.). Sunflower science and technology. Agron. No. 19, Amer. Soc. Agron., Madison, Wis.

North Mississippi Research and Extension Center. 2004. Weather data. Annu. Res. Rpt. North Miss. Res. Ext. Ctr., Miss. Agr. For. Expt. Sta. Info. Bul. 405:402-408.

Putt, E.D. 1978. History and present world status, p.1-29. In: J.F. Carter (ed.). Sunflower science and technology. Agron. No. 19. Amer. Soc. Agron., Madison, Wis.

Romo Leroux, M.J., K.W. Hood, and R.C. Sloan. 2003. Production cost for selected varieties of cut flowers in Mississippi. Annu. Res. Rpt. North Miss. Res. Ext. Ctr., Miss. Agr. For. Expt. Sta. Info. Bul. 398:464-474.

Sloan, R.C. and S.S. Harkness. 2002. Cut flower production in Mississippi. Annu. Res. Rpt. North Miss. Res. Ext. Ctr., Miss. Agr. For. Expt. Sta. Info. Bul. 386:314-336.

Sloan, R.C., S.S. Harkness, and K.W. Hood. 2003. Cut flower production in Mississippi. Annu. Res. Rpt. North Miss. Res. Ext. Ctr., Miss. Agr. For. Expt. Sta. Info. Bul. 398:372-463.

Sloan, R.C., S.S. Harkness, and K.L. Reel. 2004. Effect of spacing on sunflower production. Annu. Res. Rpt. North Miss. Res. Ext. Ctr., Miss. Agr. For. Expt. Sta. Info. Bul. 405:380-382.

U.S. Department of Agriculture. 1998 Census of horticultural specialties. USDA, Natl.Agr. Stat. Serv. 25 Jan. 2001.<http:// www.nass.usda.gov/census/census97/ horticulture/horticulture.htm>. 